Extensive improvements were carried out, including the building of a new aviary, the extension of the carnivora house, and an open arena for lions and tigers. And "all the members of the menial staff of the three Sections were provided with suitable uniforms, for the first time, with suggestive badges for the respective groups; and the whole staff looks exceedingly smart when thus arrayed on ceremonial and festive occasions. . . The year 1109 was one of the most progressive in the annals of the institution, and has marked an important land mark in the various stages of its development for years." (Administration Report to the Government of His Highness the Maha Raja of Travancore, 1109 M.E.)

\section{Marine Biology in Ceylon}

THE administrative report for 1934 of the marine biologist of Ceylon, Mr. A. H. Malpas, shows that as the results of restricted inspections by dredging of the pearl banks there were no spatfalls in the northern paars and Cheval paars. A certain number of second and third year oysters were, however, present, but not in sufficient quantities to offer a prospect of immediate fisheries, although if conditions are favourable they may provide heavy spatfalls. A scheme has been prepared for the establishment in Colombo of a fisheries research station combined with an aquarium which is under consideration. This provides in the first instance for a small biological research station capable of being enlarged as funds are available. It will be equipped with research laboratories and freshwater and marine aquaria essential for fisheries investigation work. An aquarium will be attached, to which the public will be admitted. This is an alternative scheme to one outlined in earlier reports which provided for exhaustive investigations in these waters with a modern fishing vessel equipped with the latest fishing appliances in order to determine the lines on which the local industries could be most profitably developed, which the Executive Committee for Local Administration has definitely decided to abandon. Under the new scheme, the field of research will include investigations into life-histories and general bionomics of all aquatic animals of importance in Ceylon, into the culture of pearl and edible oysters, into the farming of estuaries and fresh-water fishes and turtle, and into the importance of various indigenous larvivorous fishes in relation to the suppression of tropical fevers and the breeding and distributing of the most active forms throughout Ceylon.

\section{Baltic Countries}

The Baltic Institute, which was founded at Torun in Poland in 1926 for the investigation of Polish and Pomeranian economic problems, has widened its scope in the publication of a journal entitled Baltic Countries, which is to appear three times a year at the annual cost of five dollars. The August number contains more than a dozen articles, all in English, on various aspects-geographical, economic and historical — of Sweden, Finland,Denmark, Estonia and other Baltic lands. Russia and Germany are excluded from the scope of the review. The editorial committee of twelve is drawn from the universities of Baltic and Scandinavian countries, England and the United States. A supplement to the issue contains the first instalment of the proposed Baltic Year Book which gives the usual statistical tables. This is to be completed in four issues, and then published separately. Baltic Countries promises to be a useful addition to geographical and economic journals.

\section{Religious Broadcasting at the Eucharistic Congress}

ThE broadcasting of the services at the International Eucharistic Congress of World Catholicism at Buenos Aires in October 1934 to the largest and most widely diffused religious congregation in history was made possible by the radio telephone. On the closing day, October 14, the Pope, Pius XI, speaking into a microphone on his desk at the Vatican, gave the concluding message not only to a million worshippers kneeling in the streets of the Argentine capital, but also, by means of retransmissions from Buenos Aires to broadcasting stations on three continents, to a very considerable proportion of the clergy and laity throughout the world. In Electrical Communication of July, two papers describe the broadcasting arrangements and the radio telephone system which rendered possible this world-wide service. No longer are the delegates to these international congresses crowded together in a cathedral with straining ears. Walls or park boundaries or national frontiers or even oceans now offer no restrictions. Without wireless, the management of the large crowds drawn from a metropolitan area having nearly three million inhabitants would have presented almost insuperable difficulties. Chile, Peru and Colombia were linked up by transcontinental land lines and Uruguay by a subfluvial cable. The able and willing co-operation of the Government telephone departments of many of the leading countries in the world ensured the success of the international broadcasts.

\section{Industrial Power in Great Britain}

A $x$ the National Electrical Convention held at Bournemouth on June 3-8, a paper on industrial power supply was read by F. Forrest, H. Hobson and C. Taite. They examine very thoroughly the dependence of Great Britain upon her manufacturing industries and how much mechanical and electrical power they take. Although widely extended use is being made by industry of the public electric supply services, a still wider use is advocated, as it has a cumulative effect upon economy of production, and many of the existing mechanical power plants are not economical. The introduction of labour-saving devices has proceeded more slowly in Great Britain than elsewhere; mass production methods also are much more widely applied in the United States and Germany. Compared with her principal competitors, there is a relative deficiency in the total power equipment per wage earner of Britain. This deficiency is partly due to the nature of British industries, which demand a greater proportion of hand processes, and 
in part to their earlier and more gradual development. The percentage of workers engaged in manufacture is appreciably higher in Britain than in the United States, France or Germany. The total horse-power has advanced from $I_{\frac{1}{2}}$ horse-power per wage earner in 1907 to 2.81 per operative in 1930 . Taking the average price of coal and electric power to be 100 in 1922, their prices fell to 75 and 59 in 1932. The advent of the Grid has enabled great reductions in capital cost owing to the use of much larger dynamos. In 1934, the average size of machine ordered was 40,000 kilowatts, which is four times the average size of a generating station in 1926. Examples are given showing how the Grid is leading to the decentralisation of industry.

\section{Progress of Welding}

The new Institute of Welding founded this year amalgamates the two organisations formerly known as the Institution of Welding Engineers and the British Advisory Welding Council. An abstract of the address of the new president, Sir Alexander Gibb, to the Institute appears in the British Engineers' Export Journal for July. It is pointed out that, on the Continent, there are many buildings more than twelve stories high constructed by welding. In Great Britain the entertainment hall at Bexhill is the first large building in which welding was used. Several all-welded ships have been constructed, and have proved very successful in everyday use. In most ships, including destroyers and cruisers, bulkheads and strength decks are welded. Welded underframes will be used for the Silver Jubilee train which will run from London to Newcastle (268 miles) in less than four hours-necessitating long stretches at more than 100 miles an hour. In the United States, the Burlington Zephyr diesel high-speed train, built of welded stainless steel, attains a speed of 100 miles an hour in its daily service between Kansas City and Lincoln, doing the 251 miles in four hours. In the electrical industry, practically all the largest machines are now fabricated by electric welding. In hydroelectric development, welded high-pressure pipe lines are the standard practice. Many bridges have been constructed in this way. In Belgium two dozen truss bridges are being built over the Albert Canal, some of the spans being 250 feet long. In Germany more than two hundred railway bridges have been built with spans up to 170 feet, and road bridges with spans of 300 feet.

\section{Norman Lockyer Observatory}

THE second edition of the Handbook of the Norman Lockyer Observatory (Sidmouth : Norman Lockyer Observatory. 6d.), compiled by Dr. W. J. S. Lockyer, director of the Observatory, is dedicated to the late Miss Winifred Lockyer who until her death in July 1934 voluntarily acted as assistant secretary and librarian. The handbook refers warmly to her willing and cheerful service, and to her many generous gifts. The beginnings of the Observatory date from 1912, shortly after the retirement of Sir Norman Lockyer from the Solar Physics Observatory at South Kensington, and the transference of that Observatory to Cambridge. To promote its development, the Observatory in 1916 was formed into a Corporation. The Observatory was originally known as 'The Hill Observatory', but in 1921 the Council of the Corporation changed its name to that which it now bears as a fitting reminder of its founder's eminence in astrophysics. The principal instruments are the 12-in. McClean telescope, the 10-in. Kensington telescope and the Mond photographic equatorial. The first two are devoted to astrophysical problems 一the study of $B$-type stars which exhibit emission lines in their spectra, and the determination of spectroscopic parallaxes (of which more than 2,000 have been measured up to date) form the main investigations. The third instrument, presented to the Observatory by Sir Robert Mond four years ago, consists of a battery of four short-focus telescopes designed for photographing large regions of the sky. Of the history of the Observatory and its programme of work, the Handbook gives an interesting account, and it is well illustrated with photographs.

\section{Mining Electrical Engineering}

Aт the annual conference of the Association of Mining Electrical Engineers held in Nottingham last July, suggestive comments were made on the directions in which engineering progress could be most helpful in mining. During recent years, notable advances have been made in developing safety lamps, flameproof switchgear of all kinds and signalling. In the latter department, experiments between the surface of the ground and the workings underneath have been made with a fair amount of success by means of wireless, but sub-surface radio still remains a possibility of the future. In his presidential address, Mr. A. W. Williams, whilst admitting the progress that has been made, urged that they must never be content with the present degree of efficiency. Engineers at the present time pay special attention to standardisation. Practically every commodity used in connexion with electrical apparatus is either standardised or is being studied with that end in view. He fears that this tendency will retard efforts to further research in the directions of safety and efficiency, and tends to put a check on individual initiative and investigation. Mr. Williams does not approve of some of the devices introduced to control apparatus at a distance, for they cannot always be trusted to work satisfactorily ; they make for safety. in some ways, but increase the risks in others. From the mining engineer's point of view, they offer few, if any, compensating advantages by increasing the efficiency of coal production.

\section{Destructive Earthquakes in 1934}

IN the last two numbers of the Materiaux pour l'Étude des Calamités (79-84, 152-155; 1935), M. Charles Bois has given a list of 54 destructive earthquakes that occurred during the year 1934. The only great earthquake of the series was that of northern Bihar on January 15. Three others, one in China and two in Mexico, may have reached the highest 